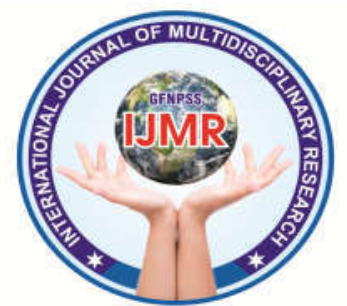

\title{
A DESCRIPTIVE STUDY TO ASSESS THE OCCUPATIONAL STRESS AND COPING STRATEGIES AMONG TEACHERS IN SELECTED SCHOOL OF DISTRICT HISAR, HARAYANA
}

\author{
SUMEDHA ${ }^{1}$, LOYD MELWYN MENDONCA ${ }^{2}$, DR SEIKHOO BISHNOI ${ }^{3}$ \\ ${ }^{1}$ Maharaja Agrasen College of Nursing, MAMC, Agroha, Hisar, Haryana, India \\ ${ }^{2}$ Professor cum HOD, Department of Mental Health Nursing, Maharaja Agrasen College of \\ Nursing, Maharaja Agrasen Medical College (MAMC), Agroha, Hisar, Haryana, India \\ ${ }^{3}$ Professor cum HOD, Department of Psychiatry,Maharaja Agrasen Medical Collage \\ (MAMC), Agroha, Hisar, Haryana, India.
}

Corresponding Email: sumedhalamba24@gmail.com

\begin{abstract}
Introduction: Stress is a common feature in our lives, especially as the pace of development increases. Work is a common term which is applied for all sorts of occupation. An occupational stress can be caused by too much or too little work, time pressure and deadlines, fatigue from physical strains of work environment, excessive travelling, long hours, having to cope with changes in work.
\end{abstract}

Material and Methods: A non experimental, exploratory research approach with descriptive research design was used to achieve the objectives of the study. Sample size was 100 teachers of District Hisar. Schools were selected by lottery method, and teachers were selected with convenient sampling technique. Data was collected through self structured occupational stress rating scale, coping strategies rating scale and demographic questionnaire.

Result: The findings of study showed that majority $2(2 \%)$ of sample had high stress and 51 (51\%) had mild stress. Majority $53(53 \%)$ of sample had good coping strategies. There is association with selected demographic variables at 0.05 level significance. There is a negative correlation founds between two variables at 0.05 level of significance.

Conclusion: The study findings provide statistical evidence which clearly indicates that there is occupational stress among the teachers, this study revealed that the teachers who have less occupational stress having good coping strategies as compared to who have high or moderate stress have bad and average level of coping strategies.

Keywords: occupational stress, coping strategies, school, teacher 
INTRODUCTION:

Stress is a many faceted process that occur in reaction to events or situations in our environment termed stressors an interesting feature of stress is the wide range of physical and psychological reactions that different people have the same event; some may interpret an event as a stressful, whereas others simply take it in stride moreover, a particular person may react quite differently to the same stressor at different point in time. ${ }^{1}$

Occupational stress is related to one's job. Occupational stress often stems from unexpected responsibilities and pressures that do not align with a person's knowledge, skills, or expectations, inhibiting one's ability to cope. Occupational stress can increase when workers do not feel supported by supervisors or colleagues, or feel as if they have little control over work processes. $^{2}$

Distress is a prevalent and costly problem in today's workplace. About one third of workers report high levels of stress. Evidence also suggests that distress is the major cause of turnover in organizations. $^{3}$
$20-30 \%$ of workers in different sectors of the European report reported in 2007 that they believed work-related stress was potentially affecting their health. In Britain, a sixth of the workforce experiences occupational stress every year. Occupational stresses and its squeal represent the majority of work-related illnesses causing missed work days. ${ }^{4}$ "Organizational interventions for improving wellbeing and reducing work related stress in teachers "Three quarters of employees believe the worker has more on the-job stress than a generation ago. ${ }^{5}$

With continued distress at the workplace, workers will develop psychological and physiological dysfunctions and decreased motivation in excelling in their position. ${ }^{6}$

Increased levels of job stress are determined by the awareness of having little control but lots of demands in the work area. ${ }^{7}$

Those in the protective services, transportation and materials moving, building grounds cleaning and maintenance, and healthcare are more susceptible to both work injuries and illnesses, as well as work related stress. ${ }^{8-9}$ 


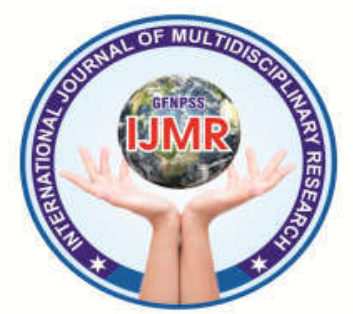

Coping of stress is described as the successful management of problems and stressful situations. The coping strategy is defined as an innate or acquired response to a changing environment or to a specific problem or a situation. According to Folk man and Lazarus, coping is the perceived and behavioural effort in order to adjust in specific external or internal requirements, which exceed the individuals' management resources. $^{10}$

\section{OBJECTIVES}

Objectives of the study are:

1. To assess the occupational stress among teachers in selected school of district Hisar,

2. To assess the coping strategies among teachers in selected school of district Hisar,

3. To find the association between occupational stress among teachers with their selected demographic variables.

4. To find the association between coping strategies among teachers with their selected demographic variables.

5. To find the co-relational between stress and coping strategies among teachers.
MATERIAL AND METHODS: The researcher used a non experimental descriptive deign is used in this study which was conducted in selected School at District Hisar. The sample size of this study was 100. Teachers of selected schools of District Hisar. Sampling technique use for selecting school was lottery method and teachers were selected with convenient sampling technique, who fulfilled inclusion criteria. Data was collected through self structured occupational stress rating scale, coping strategies rating scale and demographic questionnaire. 5-point likert scale was used as evaluation technique.

\section{RESULT}

Demographic data: - the large number $39(39 \%)$ of teachers belongs to 41-50 years of age, 32 (32\%) belongs to $31-40$ years, $16(16 \%)$ belongs to $51-60$ years, $13(13 \%)$ belongs to $21-30$ years. With regards to gender majority of samples $62(62 \%)$ were females, 38 (38\%) were male. Based on educational level majority of the samples 57 (57\%) belong to B.ed, 21 (21\%) belongs to M.ed, $11(11 \%)$ belongs to J.B.T, 11 (11\%) belongs to M.Phill, Phd teachers. 


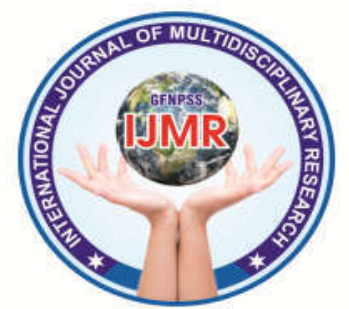

Regarding marital status 93 (93\%) were married and $6(6 \%)$ were single, $1(1 \%)$ were widow/widower Among the study samples $40(40 \%)$ were belong to nuclear family, 57 (57\%) were belongs to joint family, $3(3 \%)$ were belongs to extended family. Based on job status majority of sample 95 (95\%) were belong to permanent job, $5(5 \%)$ were belong to contractual.

Regarding job sector $80 \quad(80 \%)$ were belong to government sector, 20 $(20 \%)$ were belong to private sector. Among the study samples 33 (33\%) were belong to more experienced above 15 years, $30(30 \%)$ were belong to experience of 5-10 years, $20(20 \%)$ were belong to experience of less than 5 years, 17 (17\%) were belongs to 11-15 years of experience. The majority of sample $74(74 \%)$ were belongs to salary above 30,000, $12(12 \%)$ were belongs to salary $10,000-20,000,9$ (9\%) were belongs to salary less than $10,000,5(5 \%)$ were belong to salary 21,000-30,000.

Table No-1 Frequency and percentage distribution of samples according to their level of occupational stress. $\mathbf{N}=\mathbf{1 0 0}$

\begin{tabular}{|l|l|l|}
\hline \multicolumn{3}{|c|}{ Criteria Measure of Occupational Stress } \\
Score \\
\hline $\begin{array}{l}\text { Category } \\
\text { Score }\end{array}$ & Percentage & Frequency \\
\hline $\begin{array}{l}\text { Sever stress } \\
(111-150)\end{array}$ & $2 \%$ & 2 \\
\hline $\begin{array}{l}\text { Moderate } \\
\text { stress } \\
(71-110)\end{array}$ & $47 \%$ & 47 \\
\hline $\begin{array}{l}\text { Mild stress } \\
(30-70)\end{array}$ & $51 \%$ & 51 \\
\hline
\end{tabular}

Maximum score $=150$ minimum score $=30$ Table no 1 depict that majority 51 (51\%) of samples has mild level of occupational stress, $47(47 \%)$ has moderate level of occupational stress, $2(2 \%)$ has sever level of occupational stress.

Table No-2 frequency and percentage distribution of samples according to their level of coping strategies.

\begin{tabular}{|c|c|c|}
\hline \multicolumn{3}{|c|}{$\begin{array}{c}\text { Criteria Measure of Coping Strategies } \\
\text { Score }\end{array}$} \\
\hline Category Score & $\begin{array}{l}\text { Percentag } \\
\text { e }\end{array}$ & frequency \\
\hline $\begin{array}{l}\text { Good Coping } \\
(92-125)\end{array}$ & $53 \%$ & 53 \\
\hline $\begin{array}{l}\text { Average Coping } \\
(59-91)\end{array}$ & $47 \%$ & 47 \\
\hline $\begin{array}{l}\text { Poor coping } \\
(25-58)\end{array}$ & $0 \%$ & 0 \\
\hline
\end{tabular}

Maximum score $=150$ minimum score $=30$

Table no 2 depict that majority 53 (53\%)

of sample has good level of coping strategies, 47 (47\%) has average level of coping strategies. 


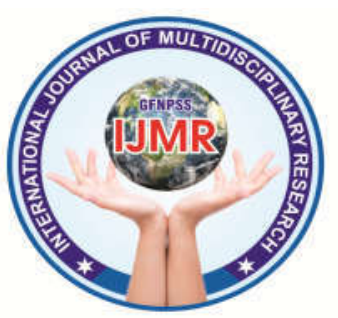

Association between occupational stress with their selected demographic variables.

There was significant association between job status and level of occupational stress as the calculated chi square value (8.336, and p Value 0.04) was more than the table value (7.815). There was significant association between experience and level of occupational stress as the calculated chi square value (16.936 and $\mathrm{p}$ value 0.05 ) was more than table value (16.919). There was significant association between salary and level of occupational stress as the calculated chi square value (41.081 and $\mathrm{p}$ Value 0.0001 ) was more than table value (16.919).There was no significance association between other demographic variables with level of occupational stress as the chi square value is less then table value.

\section{Association between levels of coping strategies of samples with their selected demographic variables.}

There was significant association between age and level of coping strategies as the calculated chi square value $(27.40$ and $\mathrm{p}$ value 0.0001 ) was more than the table value (12.59).
There was significant association between experience and level of coping strategies as the calculated chi square value (24.641 and $p$ value 0.0001$)$ was more than table value (12.592).

There was significant association between salary and level of coping strategies as the calculated chi square value (51.475 and $p$ Value 0.0001) was more than table value (12.592).

There is no significance association between other demographic variables with level of coping strategies as the chi square value is less then table value.

\section{Correlation between variables}

The correlation value is $(-0.501)$ and table value is (0.197), $\mathrm{p}$ value is (0.0001). It was implied that the teachers who have high occupational stress use less coping strategies, and the teachers who have mild occupational stress use more coping strategies.

\section{CONCLUSION}

The study findings provide statistical evidence which clearly indicates that there is occupational stress among the teachers, this study show that the teachers who have less occupational stress having good coping strategies as compared to who 


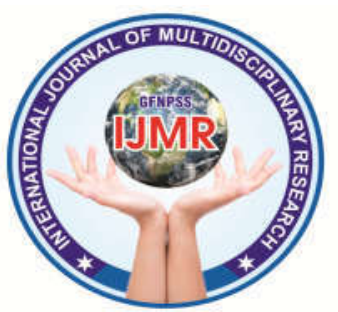

have high or moderate stress have bad and average level of coping strategies.

\section{REFERENCES}

1. Baron. A. Robert "Psychology," ed 5th.published by Dorling Kindersley (India) pvt.ltd, 2007. p.494.

2. "WHO | Stress at the work place". Www.who.int. Retrieved 2015-10-27.

3. NIOSH (1999). Stress at Work. U.S. National Institute for Occupational Safety and Health, DHHS (NIOSH) Publication Number 99-101.

4. Naghieh, Ali; Montgomery, Paul; Bonell, Christopher P; Thompson, Marc; Aber, J Lawrence; Naghieh, Ali (2015).

5. Princeton Survey Research Associates (1997). Labor Day survey: state of workers. Princeton, NJ: Princeton Survey Research Associates.

6. Olligan, Thomas W, Colligan MSW, Higgins M. "Workplace Stress -
Etiology and Consequences". Journal of Workplace Behavioral Health. (2006) 21 (2): 89-97.

7. http://www.stress.org/workplacestress/ \#sthash.Mep5bsfR.dpuf

8. Dopkeen Jonathan, Dubois, Renee "Stress in the Workplace: A Policy Synthesis on Its Dimensions and Prevalence"(2014) Available at https://en.wikipedia.org/wiki/Occupati on al_stress

9. Sabherwal Naina, Ahuja Deeya, et, al. A study on occupational stress among faculty members in Higher Education Institutions in Pune. (SIMSJMR) SIMS Journal of Management Research.March 2015; 1(18).

10. CWA Occupational Safety and Health Department 501 Their Street, New Washington, D.C.200012797Available from Webpage: www.cwasafety and health.Org.in. 